\title{
Some Points in the Morphology of the Stipules in the Stellatae, with special reference to Galium.
}

BY

\author{
H. TAKEDA, D.I.C.
}

With twenty-seven Figures in the Text.

$\mathrm{T}^{\mathrm{T}}$ is hardly necessary to recapitulate here the results of the previous 1 investigators on the nature of the leaf-like organs or 'leaves' in the apparent whorls of Galium, and of many other members of the Stellatae (or Galieae, a tribe of the Rubiaceae). There is little doubt that in any whorl the two opposite 'leaves', one at any rate of which subtends an axillary shoot, are the true leaves, while the other members at the same node are stipules. Thus, in the case of a six-membered whorl there are two leaves, each of which is provided with two stipules. Where only five or four ' leaves' occur in a whorl, it is usually understood that in the first case one, and in the second case both, pairs of stipules have undergone a concrescence. If, however, more than six 'leaves' are present in a whorl, it is explained that one or more of the original four stipules have undergone chorisis, resulting in the production of supernumerary members. ${ }^{1}$

Eichler found in Galium Mollugo and also Rubia tinctorum, that there are often two primordia which fuse, giving rise to a single interfoliar stipule on either side of the stem. ${ }^{2}$ Goebel, ${ }^{3}$ on the other hand, found in

1 Cf. de Candolle, Vegetable Organography (Engl. ed.), vol. i (184I), p. 286; Le Maout et Decaisne, Traité général de Botanique, p. I5 (1868); Leunis, Synopsis der Pflanzenkunde, ed. 3 , i, p. I93 (I883); Pax, Allgemeine Morphologie der Pflanzen, p. 102 (I890); Velenovsky, Vergleichende Morphologie der Pflanzen, pt. 2, p. 433 et seq. (I907); Worsdel, Principles of Plant-Teratology, vol. i (1915), p. 172. It may be of some interest to mention that Wydler, who recorded the occurrence of a complete fission of a stipule into two separate organs in Galium Cruciata, Linn. (in Flora, vol. xlii, 1859, p. 10), suggested that each of the apparently single stipules in this species may be the product of a fusion of two separate organs. 'If so,' he says, 'the formation of a midrib (indistinguishable from the midrib of the true leaves) on the common border of two fused stipules is remarkable. The midrib in the (fused) stipules would then correspond to commissural ribs, like those for example in a gamosepalous calyx.'

2 Eichler, Entwickelungsgeschichte des Blattes, \&c., p. 32, Taf. i, Fig. 18 (I86I). Pax (1. c.) follows this view, and gives Galium rotundifolium and $G$. palustre as examples.

3 Vergleichende Entwickelungsgeschichte der Pflanzenorgane. Schenk's Handbuch der Botanik, iii (1884), pt. I, Fig. $4^{8}$ B, p. 23 I. See also Goebel, Organography of Plants (Engl. ed.), pt. 2 (1905), p. 369 .

[Annals of Botany, Vol. XXX. No. CXVI!I. April, ıg16.] - 
Galium palustre that the concrescence of two stipular primordia, as described by Eichler, is of very rare occurrence, and that, as a rule, only a single primordium gives rise to a single stipule.

Franke, ${ }^{1}$ who had fresh material of a good many species of Galium and other genera of the Stellatae at his disposal, has confirmed Goebel's observations, and states ${ }^{2}$ that the four-membered whorls in the Stellatae arise without exception from four uniform protuberances. He reached the conclusion by investigation of Galium aetnicum, $G$. boreale, G. Cruciata, G. lucidum, G. Mollugo, G. parisiense, G. physocarpum, G. pusillum, G. recurvum, $G$. rubioides, $G$. saccharatum, $G$. sylvestre, $G$. tenuissimum, G. verum, and several other members of the Stellatae, including Rubia tinctorum.

It seems worth while, therefore, to inquire how far the feature described by Franke is general, and also whether there is any further evidence for Eichler's statement.

Penzig ${ }^{3}$ records that in Rubia peregrina one often finds whorls in which two forked stipules occur opposite one another, or, where the fission is complete, that six 'leaves' (i. e. two leaves and the two pairs of stipules belonging to them) are present at a node. He also mentions ${ }^{4}$ that in Galium Cruciata the stipules are occasionally partially or completely divided, so that whorls with one or two of the laminae forked, or with five to six separate members, arise.

The writer can add Galium gracile, Bunge, ${ }^{5}$ as giving an example of a similar phenomenon. This species, which is widely distributed over Japan and China, constantly possesses four 'leaves' at each node, two being the true leaves and the other two stipular. Although no specimen has ever been found with more than four 'leaves' at a node, examples are however fairly frequent in which one or both of the stipules of a whorl have two midribs, indicating their double nature. The apex of the stipules with double midribs is usually more or less indented, but cases are occasionally found in which the apex is almost entire. There also occur, though less frequently, stipules with a forked midrib. Figs. I- 8 have been selected from two specimens of this plant gathered by Swinhoe in the interior of Amoy, China, to illustrate these features. Fig. I represents an ordinary stipule which possesses a single midrib and two lateral veins, and assumes exactly the same shape and size as the true leaf. Fig. 2 is

1 Beiträge zur Morphologie und Entwickelungsgeschichte der Stellaten. Botanische Zeitung, vol. liv (I896), pt. I, p. 33 et seq.

${ }^{2}$ Franke, l. c., p. 5 o.

3 Pflanzen-Teratologie, systematisch geordnet, vol. ii (I894), p. 37 .

1 Penzig, l. c., p. 38.

5 Enumeratio plantarum quas in China boreali collegit (1832), p. 35. For a more detailed description see Makino in Tôkyô Botanical Magazine, vol. xvii (1904), p. 74. The plant has also been described as G. miltorrhizum: Hance, in Seemann's Journal of Botany, vol, vi (I868), p. I 4. 
a similar stipule, but the midrib is forked at the tip, obviously indicating the fused nature of the stipule. Fig. 3 shows the midrib still more deeply forked, the apex of the stipule being at the same time slightly indented. Fig. 4 has two complete midribs as well as the two lateral veins which are normally present, while the apex of the stipule is very shallowly indented. This is the type of the double stipule which commonly occurs in this species. Fig. 5 shows a shallow notch at the apex, while one of the two midribs is provided with two lateral veins; one of the latter being in the middle region of the stipule. Figs. 6 and 7 are stipules with a deeper notch at the apex and exemplify a type of much less common occurrence. Fig. 8 shows the deepest cleft the writer has seen.

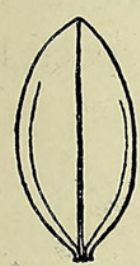

FIGS. I.

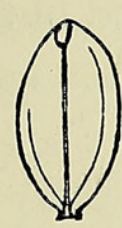

2.

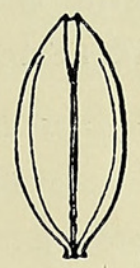

3 .

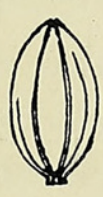

4 .

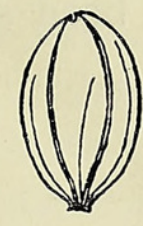

5 .

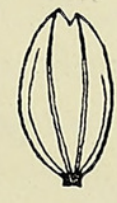

6.

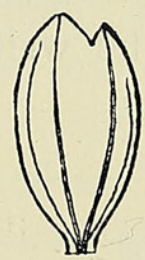

7.

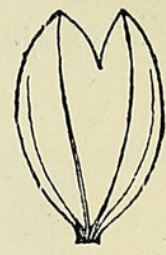

8.

FIGs. I-8. Stipules of Galium gracile, Bunge. All $\times \mathbf{1} \cdot 5$. Explanation in the text.

It is obvious that the appearance of a double midrib is not due to an abnormally strong development of one of the lateral veins, since the lateral veins are always present in the stipules, whether they have one or two midribs. Moreover, the midrib may sometimes fork into two, as shown in Figs. 2 and 3 , and this phenomenon is held to be a step towards the production of two complete midribs. The stipule with two midribs and three lateral veins (Fig. 5) represents the nearest approach observed to a separation of the stipule into two complete organs. Since the development of the leaves and stipules could not be investigated in the material at the writer's disposal, it is impossible to state definitely whether the ordinary stipules (i. e. those with a single midrib) are always produced as the result of a true concrescence of two primordia. It is quite possible that each of the ordinary stipules is usually produced from a single primordium, and that two types of development may be found in one and the same species.

Another instance is afforded by Galium paradoxum, Maxim., ${ }^{1}$ which also is a Far Eastern species. ${ }^{2}$ This plant possesses four 'leaves' at each

1 Bulletin de l'Acad. Imp. de St.-Pétersb., vol. xix (1873), p. 28 r.

2 This species was first discovered in Manchuria in 1860. Later, in 1879, Franchet and Savatier (Enum. Pl. Japon., vol. ii, p. 392) recorded it from Japan. Its occurrence in China (Hupeh) was first made known by Diels (Engler's Bot. Jahrb., vol. xix, I90I, p. 583), and in Korea by Kamarov (Flora Manshuriae, vol. ii, 1907, p. 497). It is not uncommon in the mountainous disticts of Japan, but is apparently scarce in China. From the latter country the writer has seen the following specimens : Hupeh, Chienshih (Henry, No. $5^{8} 5 \mathrm{I}$ ), Patung (Henry, No. 6026), Changyang (Wilson, No. II53), Yunnan; ad collem Yen-tze-hay, alt. 3,200 m. (Delavay, No. 3102). 
node in the middle and upper parts of the stem, i.e. two true leaves and two stipules, the latter resembling the former, but easily distinguishable from the true leaves at the same node by the fact that they are often smaller, and also that they are always bearded at the base of the petiole. In the lower part of the stem there are again two interfoliar stipules, which, however, are quite distinct in appearance from the true leaves, being small and scale-like. They are subulate or triangular, membranous, often thinly ciliate on the margin, and also more or less barbate at the base (Fig. 9). In one of the specimens collected on Mt. Fuji in I887, and sent to Kew from the Tôkyô Imperial University, the writer found a small, scale-like stipule with a forked midrib at a node in the lowermost region of the stem, the apex of the stipule being at the same time slightly indented (Fig. 10). The writer has not been so fortunate as to find in this species

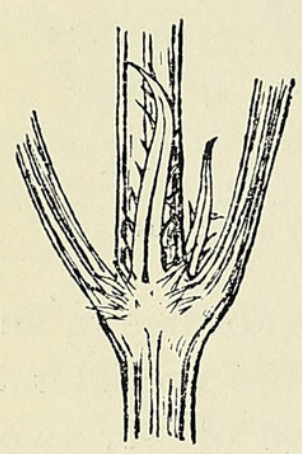

Figs. 9.

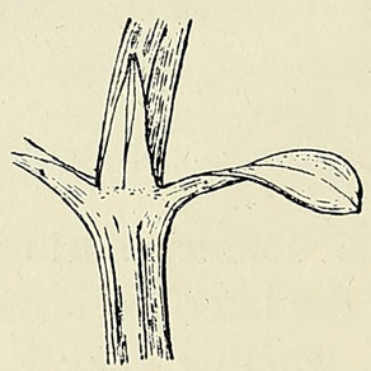

10.

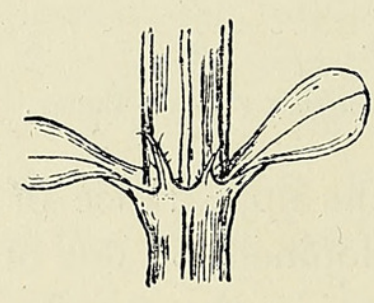

I I.

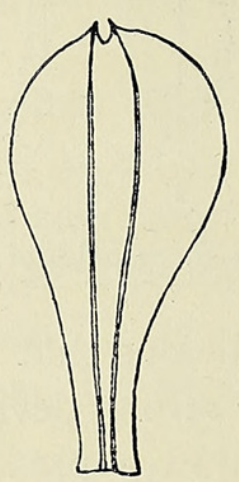

I 2.

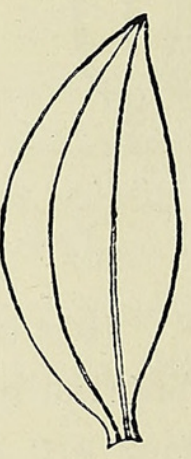

I3.

FIGS. 9-II. Galium paradoxum, Maxim., showing scale-like interfoliar stipules from the lower region of stem. Figs. 9 and $11, \times 7$, fig. I0 $\times 6$. Fig. I 2. Galium saxatile, Linn. Stipule with two separate midribs. $\times 6$. Fig. I3. Asperula asterocephala, Bornm. Stipule with two separate midribs. $\times 2$.

any stipules with two separate midribs. A case has, however, been found in which two separate, small, scale-like stipules are present on one side of a node near the very base of the stem of one of the specimens gathered by Wilson in Changyang, in the province of Hupeh, China (Fig. II).

A third instance of 'four-leaved' species occasionally producing stipules with two midribs is presented by Asperula asterocephala, Bornm. ${ }^{1}$ This handsome perennial, which was discovered by Bornmüller in Kurdistan, attains a height of about $40 \mathrm{~cm}$., and always bears four 'leaves' at each node, just as the first example given above. The stipules can readily be distinguished from the true leaves by the fact that they are always distinctly smaller than the latter at the same node, and one-nerved, while the true leaves are often provided with one or two lateral veins on either side of the midrib. Towards the apex of the stem the stipules become very much reduced in size, often to such an extent as to appear almost scale-like,

1 In Mittheil. Thür. Bot. Ver., N. Folge, vol. vii (1895), p. 7 . 
although they are always green and not scarious, thus differing from the scale-like stipules at the lower nodes in Galium paradoxum, Maxim. In one of the co-type specimens of $A$. asterocephala, which was distributed under J. Bornmuiller, Iter Persico-turcicum, No. I337, the writer found at the third node from the base a stipule having two midribs, while its general appearance is very similar, except for size, to the true leaves at the same node (Fig. I3). So far as has been seen, the occurrence of stipules of this nature seems to be rare in this species.

As another instance, Galium leiophyllum, Boiss. et Hohenack., ${ }^{1}$ in which the writer found a stipule of a double nature, may be briefly described below. This plant is of moderate size ${ }^{2}$ and bears five, or more often six 'leaves' to a node. In one of the specimens distributed under J. Bornmüller, Iter Persicum alterum, No. $7105,{ }^{3}$ the writer found below the middle region of a stem (about the fifth node from the base) a whorl consisting of two true leaves and two stipules, one of the latter being furnished with two midribs (Fig. 2I). The node immediately above and that below this whorl bear five 'leaves' each, and all the nodes in the higher region of the same stem are six-membered.

The writer also found in a specimen of Galium saxatile, Linn., which he collected himself in England in I9I5, a stipule with two midribs. It occurred in a four-membered whorl which was preceded by a five-membered whorl, and succeeded by a six-membered one (Fig. I 2).

Further cases of the occurrence of stipules of a double nature in fourmembered whorls have been found in Asperula arvensis, Linn. (Fig. I9), A. sherardioides (Boiss.), Jaub. et Spach. (Fig. 20), and A. aspera (M. Bieb.), Boiss., to each of which further allusion will be made later on.

It may, therefore, be not unreasonable to conclude from the instances above referred to, that in certain species of Galium and some other members of the Stellatae, such as those which were investigated by Goebel and by Franke, each stipule in a four-membered whorl arises from a single primordium, while in some species such as G. gracile, G. paradoxum, G. leiophyllum, and G. Cruciata, and the three species of Asperula above referred to, stipules are occasionally produced as the result of a coalescence of two primordia. The first case is regarded as a congenital concrescence, ${ }^{4}$ while the second is a true concrescence, and at the same time points towards the production of more than two stipules at a node.

In regard to the whorl with five members, mention has already been made above of the result of the investigation carried out by Eichler, ${ }^{5}$ who found in Galium Mollugo that two stipular primordia on one side of a node

1 Boissier, Diagnoses, vol. i. 3 (I843) p. $3^{6}$; Ejusd. Fl. Orient., vol. iii. (1875), p. 5 I.

$230-45 \mathrm{~cm}$. in height.

3 This specimen is to be referred to var. subvelutinum : Boiss., 1. c.

4 Goebel, 11. cc.

5 1. c., p. 32, Taf. i, Fig. 15. 
fuse, and thus give rise to a single stipule, while each of the two stipular primordia on the other side of the same node develops into a separate organ.

Franke, ${ }^{1}$ on the other hand, states that in this case the solitary stipule on one side of the node is produced from a primordium which is homologous with a stipular primordium of the four-membered whorl, while the paired stipules on the other side of the node arise from a common arc-like protuberance, which is from the beginning distinguishable by shape and insertion. The latter phenomenon is, however, not to be considered as a fission in the proper sense. In other words, each of the three stipules in the five-membered whorl arises from a single primordium, and there is no evidence of a true concrescence of two stipular primordia giving rise to a single organ.

So far as the writer's own observations go, stipules of a double nature are very rarely met with in five-membered whorls. The only plant in which such an occurrence has been found is Asperula aspera (M. Bieb.), Boiss. (Fig. 22). This case, however, gives sufficient evidence for the conclusion that stipules are occasionally produced also in five-membered whorls as the result of a true concrescence of two primordia. A further reference to this plant will be made later on with regard to the distribution of double stipules.

As to the case in which more than six members occur in a whorl, it is regarded that in addition to the two true leaves there are more than two stipules on one or both sides of the stem. Eichler ${ }^{2}$ found in Galium Mollugo that a new tissue arises between the original two stipular primordia and produces an independent organ resembling the other stipules. If this phenomenon takes place on one side only of a stem, there would be five stipules produced. If, however, a new tissue between two primordia occurs on both sides of the stem, there would be six stipules formed, thus making the whorl eight-membered at a node.

Franke ${ }^{3}$ has confirmed Eichler's observations, and states that he found in Asperula odorata and $A$. azurea a new primordium arising between two stipular primordia on one or both sides of the node, the former being distinguishable from the latter by its smaller size.

Neither of these investigators has examined any whorl with more than eight members, although there are certain species of Galium, such as G. verum, Linn, and of some other genera, e. g. Asperula odorata, Linn., which often bear more than eight, and, particularly in the former plant, up to twelve, foliar members (i. e. two true leaves and ten stipules) at a node.

Unfortunately, the writer's own observations on these pleiomerous whorls in herbarium material cannot throw any light upon the subject. It may, however, be presumed that there arise as many primordia as there

$$
{ }^{1} \text { 1. c., p. 50. } \quad 2 \text { 1. c., p. 32, Taf. i, Figs. I6, I } 7 .
$$

3 1. c., p. 5 I, Taf. i, Figs. 7,8 . 
are 'leaves' at a node. Thus, as many as five stipular primordia may occur on either side of a node.

In this connexion mention may be made of some interesting features exhibited by Didymaea mexicana, Hook. fil., ${ }^{1}$ which also belongs to the Stellatae. As a unique character ${ }^{2}$ of this (monotypic) genus the plant has been described as having each of its (opposite) leaves provided with a pair of typically differentiated stipules, the latter being subulate or lanceolate and quite distinct from the true leaves. ${ }^{3}$

In Didymaea there are as a rule four scale-like stipules at a node, ${ }^{4}$ but very often three stipules are present on one or on both sides of the stem, and the middle or additional one is then distinctly smaller than either of the other two (Figs. 14, I 5). ${ }^{5}$ This feature reminds one of the primordial stage of the seven- or eight-membered whorls in Asperula. ${ }^{6}$ Although nothing is known about the development of the foliar organs in Didymaea, it

1 In Benth. et Hook., Genera Plantarum, vol. ii (I873), p. I50; Hooker's Icones Plantarum, vol. xiii $(\mathrm{I} 878)$, p. 55 , tab. $127 \mathrm{I}$.

2 That is, unique among the Stellatae.

3 K. Schumann gives in Engler and Prantl's Pflanzenfamilien, vol. iv (I89I), pt. 4, p. 3, Rubia diphylla, K. Schum., as another example of a member of the Stellatae having ordinary triangular stipules. Neither the figure he refers to nor a description of this plant has ever been given. There is, however, little room for doubt that this name (nom. nud.) is a synonym of Rellunium diphyllum, K. Schum. (apud Martium, Flora Brasil., vol. vi, pt. 6, I888, p. II 7 ; also see under this genus in the Pflanzenfamilien, vol. iv. p. 154). This plant possesses a minute triangular interfoliar stipule on either side of the node, just as in Rubia ephedroides, Cham. et Schltdl. (Linneae, vol. iii, I828, p. 23I ; also see Martius, Fl. Brasil., vol. vi, pt. 6, p. I 20, Tab. xciii, Fig. I), and $R$. equisetoides, Cham. et Schltdl. (1. c., p. 23I ; Martius, 1. c., p. 119). These three plants are, however, apparently xerophytes and have their foliar organs very much reduced; the true leaves being scale-like, three or four $\mathrm{mm}$. in length, and only a little larger than the stipules, which are similar in shape. It is possible that if the true leaves could be induced to develop to a respectable size, the stipules would also become much larger, assuming exactly the same shape as the former. It is therefore obvious that these three species are not suitable as examples of the exceptional phenomenon among the Stellatae of scale-like stipules alternating with the true leaves, which are decussate and of normal appearance. So far as the writer knows, Galium paradoxum, Maxim., G. geminifolium, F. von Müller, Asperula geminifolia, F. von Müller, and Didymaea mexicana, Hook. f., are the only members of the Stellatae showing this rare phenomenon, and of these the first-named plant produces scale-like stipules at the lower nodes only, those at the middle and upper nodes of the stem being leaf-like. Both Galium geminifolium and Asperula geminifolia are Australian plants (cf. Bentham, Flora Australiensis, vol. iii, 1866, pp. 445 and 443), and usually bear at each node two opposite, narrow leaves, and two small scale-like stipnles alternating with the former (cf. K. Schumann, in Engler and Prantl, PHanzenfamilien, vol. iv, pt. 4, p. I5 I, Fig. 48 D). In G. geminifolium, however, the stipules are occasionally well developed, either becoming leaf-like or showing a transition. This is probably due to a change in some physiological conditions (such as might be caused by rain, \&c.) at the time when the foliar organs are developing.

It may be remarked here that Velenovsky (1. c., p. 434) gives Putoria as an example of the genera which belong to the Stellatae and bear interpetiolar stipules alternating with two opposite leaves. However, all the leading systematists agree to refer this genus to the tribe Anthospermeae !

${ }^{4}$ Cf. K. Schumann, in Engler and Prantl, Pflanzenfamilien, vol. iv, pt. 4, p. I47, Fig. 47, N, o.

5 Only once has the writer met with four stipules on one side of a node; this was in one of the specimens distributed under Pringle, Plantae mexicanae, No. 4716 (1894). In this case also, the two middle ones are smaller than the other two stipules.

${ }^{6}$ Cf. Franke, l. c., p. 5I, Taf. i, Fig. 8. 
may be presumed that each of the three stipules arises from an independent primordium. The middle stipule, as a rule, shows no definite connexion with either of the adjacent stipules. The writer has, however, found a case in which one of the two stipules on one side of a node is divided about half-way into two unequal parts (Fig. I6), ${ }^{1}$ thus suggesting how three stipules may have arisen from two by fission of one of them, that is, if two be taken as representing the fundamental number of stipules on each side of the node.

A feature of further interest has also been found in several specimens examined of Didymaea, the paired stipules on either side of the stem being not uncommonly united into a single organ, with the lamina either deeply or shallowly divided (Figs. I7, I8). There is, of course,

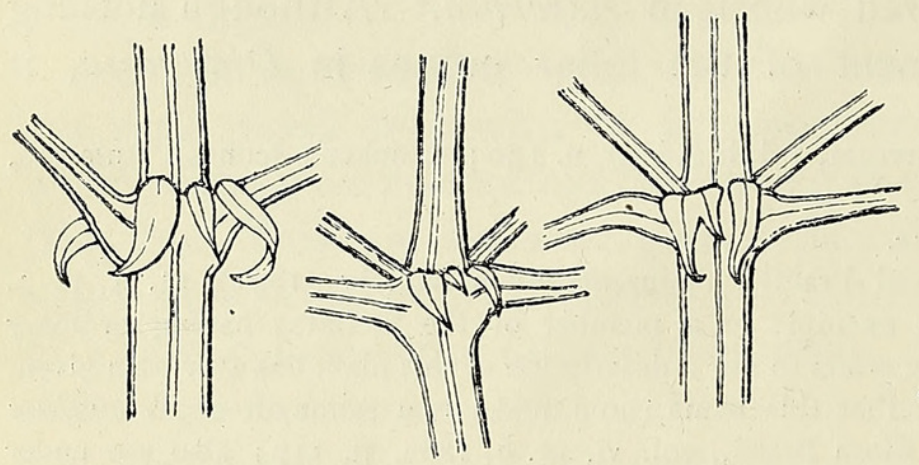

FIGS. I4.

I5.

I6.

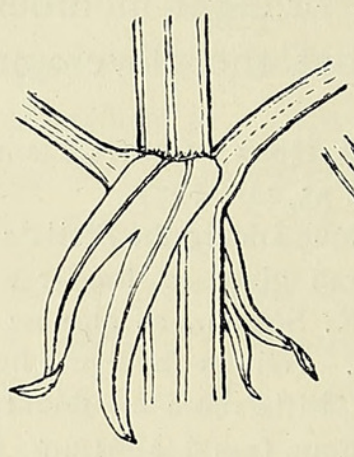

I7.

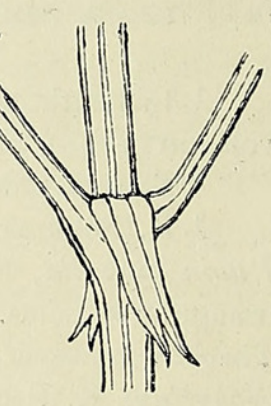

I8.

FIgS. I4-18. Interfoliar stipules of Didymaea mexicana, Hook. fil. All $\times 5$. (Figs. I 5 and 16 were taken from inflorescence, the others from stem.) Explanation in the text.

no shadow of doubt that these single stipules with a forked lamina are produced as the result of a concrescence of two separate primordia. The question then arises whether the presence of a single stipule on either side of the stem should be considered as the more primitive type, and if this were so, whether the occurrence of two to three separate stipules on each side of the node might be regarded as the result of a fission of the original single interfoliar stipules.

A comparison of the different features found in Galium and other genera with those just described above for Didymaea will bring forward the more general question: whether the six-membered whorl in the Stellatae should be regarded as having been derived from a fourmembered whorl, owing to chorisis of an original pair of opposite interfoliar stipules, or whether, on the other hand, the production of only two stipules at a node is due to reduction.

An examination of the seedlings may throw some light on the problem, since early stages in ontogeny often show some ancestral characters. ${ }^{2}$

${ }^{1}$ Unfortunately, the material was unsuitable for determining whether the two midribs of this stipule are completely separate or united near the base of the organ in question.

${ }^{2}$ It is not maintained that characters observed in early stages of ontogeny are necessarily to be 
According to Lubbock ${ }^{1}$ the seedlings of Galium saccharatum and G. temiissimum, both of which usually bear more than six 'leaves' at each node, produce only four 'leaves' (i. e. two true leaves and two stipules) at the first node, five 'leaves' at the second, and often six 'leaves' (i. e. the two true leaves and four stipules) at the third node. The same author states $^{2}$ that the seedling of Sherardia arvensis possesses only a single stipule on each side of the stem at the first three nodes, and that four stipules (two on each side) occur at the succeeding nodes. Velenovsky ${ }^{3}$ states that in the seedling of Asperula odorata the cotyledons are succeeded by a four-membered whorl, in which two stipules (smaller) are distinctly enveloped by two opposite leaves. In the next whorl there are six 'leaves', and the two opposite leaves again surround the four stipules, which are produced by a fission of those organs which correspond to the original two opposite stipules at the first node. He further states $^{4}$ that similar features may be seen also in Galium sylvaticum, the seedlings of which however produce four-membered whorls throughout the first year's growth.

The writer's own observations on seedlings have revealed more instances of the same phenomenon in other members of the Stellatae. Galium murale, All., always produces four 'leaves' at each of the lower nodes, and five or six 'leaves' at the upper nodes. Both $G$. setaceum, Lam., ${ }^{6}$ and Crucianella disticha, Boiss., ${ }^{7}$ bear four leaves at the first, and often up to the third node, and six 'leaves' at each of the higher nodes. G. Vaillantii, DC. ${ }^{8}$ which possesses eight ' leaves' at each node in the upper region of the stem, produces four ' leaves' at the first, and sometimes also at the second node, but five or more 'leaves' at each of the nodes at a slightly higher level. G. Aparine, Linn., usually produces four 'leaves' at the first, and sometimes the second node, and less commonly five or six 'leaves' at the first node. In Crucianella angustifolia, Linn., and C. patula, Linn., the first and often the second and third nodes have a whorl of four members, while each of the higher nodes is furnished with a six-membered whorl. C. latifolia, Linn., which is another 'six-leaved' species, bears four

accepted as ancestral (cf. Lang, Address to the Botanical Section, Brit. Ass., at Manchester, I9I5, p. 6). Any given case, relating for instance to the leaves of a seedling, must be studied in the light of as much collateral evidence as is available, and a slight presumption in favour of ancestral character may be granted on the strength of a number of examples, such as the seedlings of the gorse, certain phyllode-bearing acacias, many Conifers (cf. Veitch's Manual of the Coniferae, ed. 2, p. 22 et seq., I900), \&c.

1 Seedlings, vol. ii (1892), p. 77 .

2 Lubbock, 1. c., p. 79.

3 1. c., pp. 434-5.

4 Velenovsky, 1. c., p. 435 .

5 Fl. Pedemont, i, p. 8, Tab. 77, Fig. I (I785); a Mediterranean species.

6 Encyclopédie, vol. ii (I806), p. 584 ; a Mediterranean and temperate Asiatic species.

7 Diagnoses, vol. i, pt. 3 ( 1843 ), p. 25 .

8 Flore de France, no. 338I ( 1805 ); Prodromus, vol. iv (I830), p. 608. The plant is sometimes treated as a variety of $G$. Aparine, Linn., var. Vaillantii, Koch, or a subspecies of $G$. Aparine, Linn. : see Hooker's Stud. Fl., ed. 3 (I884), p. I94. 
' leaves' at each of the first few nodes, or often for several nodes. Mericarpaea vaillantioides, Boiss., a small annual plant from Assyria, is described by some authors as having four 'leaves' at each node, ${ }^{2}$ and by others six 'leaves'. ${ }^{3}$ This discrepancy is due to the fact that the plant actually bears four ' leaves' at each of the lower nodes, and six 'leaves' to the node in the upper region of the stem. A highly interesting feature is furnished by a specimen of Asperula arvensis, Linn., which usually produces four 'leaves' at the first node, and five or six members at the second. The specimen under consideration is one of those distributed under Siehe's Botanische Reise nach Cilicien, No. 144. One of the two stipules at the first node

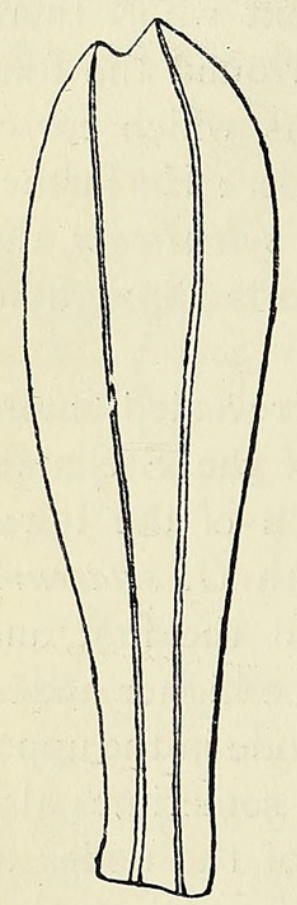

FIgS. I9.

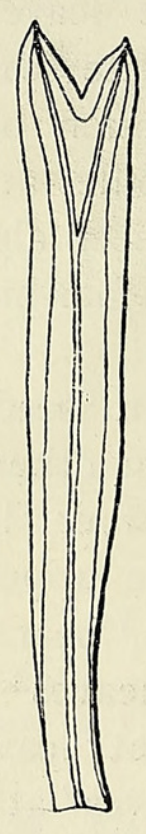

20.

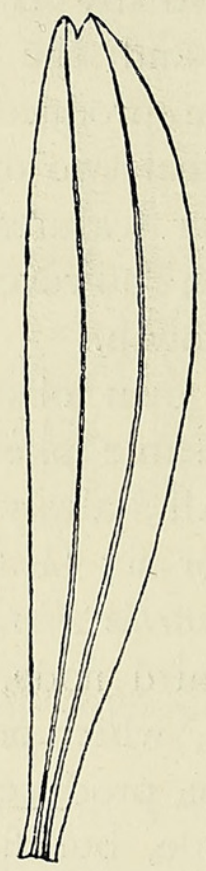

$2 \mathrm{I}$.

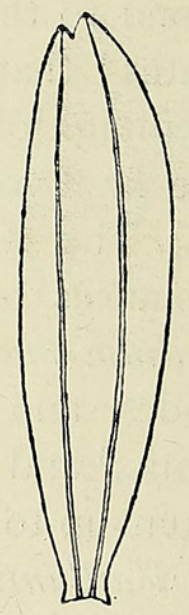

22.

Fig. I9. Double stipule of Asperula arvensis, Linn. $\quad \times 5$. Fig. 20. Forked stipule of Asperula sherardioides, Jaub. et Spach. (seen from under surface, showing forked midrib and recurved margin of lamina). $\times 5$. Fig. 2 I. Double stipule of Galium leiophyllum, Boiss. et Hohenack. $\times 5$. Fig. 22. Ditto of Asperula aspera, Boiss. $\times 5$.

in this particular specimen is provided with two midribs and a notched lamina (Fig. I9), evidently showing a transition to the five-membered whorl at the next node. A specimen of Asperula sherardioides (Boiss.), Jaub. et Spach., ${ }^{4}$ has also been found to exhibit a similar phenomenon. This Persian plant is a small annual and does not attain more than $10 \mathrm{~cm}$. in height. The first node usually possesses four, but very rarely six 'leaves', while the second node has five or six leaves, or occasionally four.

1 Diagnoses, vol. i, pt. 3 (1843), p. 52. Cf. Hook. f. in Benth. et. Hook., Gen. Pl., vol. ii (I 873$)$, p. I 49 .

2 Cf. Hook. f. in Benth. et Hook., Gen. Pl., vol. ii (1873), p. I49.

3 Cf. Boissier, Fl. Orient., vol. iii (1875), p. 83 .

4 Illustr. Pl. Orient., vol. i (1843) p. I53, tab. 83; Boissier, Fl. Orient., vol. iii (I875), p. 29. The plant was originally described under the name of Crucianella sherardioides, Boiss. : Diagnoses, vol. i, pt. 3 (I 843 ), p. 24 . 
The particular specimen referred to above was distributed under No. 7093 of J. Bornmuiller, Iter Persicum alterum. It measures about $4 \mathrm{~cm}$. high, and possesses four 'leaves' at each of the first two nodes, while the third node, which is situated immediately below the inflorescence, has six 'leaves'. One of the two stipules of the second node has the lamina and midrib forked (Fig. 20), while the other is normal.

It is therefore evident that, so far as our knowledge goes, in Galium and in some allied genera, the species with several to many 'leaves' at each node generally start in the seedling with a four-membered whorl, which is succeeded by whorls consisting of a larger number of 'leaves'.

Correlating these facts, it appears probable that in the Stellatae the fourmembered whorl (composed of two true leaves and an interfoliar stipule on each side of the stem) represents the more primitive type, while the whorls with more than four members (i. e. with more than two stipules) represent a derived type.

In connexion with the arrangement of 'leaves' in the seedlings, it may be of no little interest to examine the manner in which double stipules (i. e. those with a forked or double midrib) are distributed on the stem of adult plants, and their relation to the 'leaves' at the neighbouring nodes. Among the three 'four-leaved' species of Galium above mentioned, $G$. gracile, in which double stipules are frequently met with, produces the stipules of this nature generally in the middle and upper regions, and only rarely near the base of the stem. If a double stipule is present at a node, it is often found that a few succeeding nodes also bear one or two stipules of the same character. In some cases, double stipules may be found at several nodes on a stem, while in the more usual cases such stipules are produced only at one or two nodes. Asperula trifida, Makino, ${ }^{1}$ furnishes us with a more interesting case. This rare species is a perennial, and occurs in certain mountainous districts of Japan. The plant was described as having 'leaves four-rarely five-verticillate', but it occasionally produces as many as six 'leaves' at a node. The specimens examined were gathered on Mount Ishidzuchi, in the Province of Iyo, in August, 1888, and were sent to Kew from the Tôkyô Imperial University. They bear four, more usually five, 'leaves' at each of the lower nodes, and often six 'leaves' to the node in the middle region of the stem (vide infra). Towards the upper part of the stem, a six-membered whorl is as a rule suddenly succeeded by four-membered whorls. Those whorls which are situated in close proximity to the inflorescence have the stipules much reduced in size. ${ }^{2}$ The arrangement of the 'leaves' in one of the specimens

1 Illustr. Fl. Japan, vol. i, No. II (I89I), p. 2, tab. 68; and in Tôkyô Bot. Mag., vol. xvii (1903), p. 72 .

2 See the excellent figures by Makino, l. c. This feature is often met with in the Stellatae. It is especially noticeable in such a species as Asperula asterocephala, Bornm., above referred to. 
examined shows the following sequence : the first node of the aerial stem, which is continuous with a rhizome, has four 'leaves', the second five, the third four (?), ${ }^{1}$ the fourth five, the fifth four, the sixth four (?), ${ }^{1}$ the seventh to ninth six each, the tenth four 'leaves', one of the two stipules having a forked midrib (Fig. 23) ; the eleventh again bears four 'leaves', and one of the stipules, which are smaller than the true leaves at the same node, has a slight indication of a double nature; the twelfth, which is giving off a branch terminated with an inflorescence, has four members with the two stipules markedly smaller than the true leaves at the same node; the thirteenth whorl, which is at the ultimate node on the stem, consists of two true leaves $(7$ to $8 \mathrm{~mm}$. long), and a small but normal stipule $(4 \mathrm{~mm}$. long) on one side, and two minute stipules $(2 \mathrm{~mm}$. long) on the other side of the node. From this node three peduncles have sprung, two of which have at their first (and only) node two small true leaves only, stipules being completely suppressed, while the remaining peduncle bears at its lowest node a pair of true leaves and a minute stipule ( $\mathrm{mm}$. long) on one side of the stem. Another specimen examined shows a somewhat similar feature : at the first and second nodes the 'leaves' have withered and are torn off; the third node, which is very similar in appearance to the fifth node of the first. specimen above described, has five 'leaves'; the fourth node bears four 'leaves', and one of the stipules is equal to the true leaves, while the other is broader and is provided with two midribs (Fig. 24); the fifth to seventh nodes are all six-membered; the eighth node has four 'leaves', and one of the stipules of this whorl possesses a forked midrib, and is exactly the same in appearance as that delineated in Fig. 22, while the other is normal; the ninth node is again four-membered but without any double stipule; the tenth node is similar in every respect to the eighth node, with this difference, that the midrib of the double stipule is more deeply forked (Fig. 25); the eleventh (ultimate) node is also four-membered, with two stipules considerably smaller than the true leaves. At the ultimate node of another specimen the writer found two true leaves ${ }^{2}$ and two stipules, the latter being much reduced in size, and one of them being provided with two complete midribs (Fig. 26). ${ }^{3}$

As has already been mentioned above, the occurrence of double stipules in the case of nodes with more than four 'leaves' is very rare.4 The only instance the writer has found is presented by Asperula aspera

1 The whorl has been damaged, and consequently it is very difficult to determine this point with absolute accuracy.

2 One of these leaves is shown in Fig. 27 for comparison.

3 Since this species bears flowers with a usually three-, often four-, and rarely five-lobed corolla, a search was made with a view to detect corolla-lobes with a forked vein. Unfortunately, the result has so far been negative. A propos, it may be mentioned that Galium saxatile, Linn., also produces pentamerous flowers very frequently.

${ }^{4}$ No case in which a double stipule occurs in a whorl with more than five 'leaves' has been observed or recorded. 
(M. Bieb.), Boiss. ${ }^{1}$ This plant, which is a native of the Caucasus and Persia, usually has six 'leaves' to a node. In the upper region of the stem of one of the specimens collected by Szovits in Persia and sent to Kew from the Imperial Botanic Garden in Petrograd, the writer found a whorl consisting of two true leaves and three stipules, one of which is provided with two midribs, the lamina being at the same time very shallowly notched at the apex. Unfortunately, the specimen is unsuitable for examining the number of 'leaves' at the next nodes above and below the one just mentioned. In this plant, branches are given off from several of the lower nodes. The branches usually start with nodes which bear four 'leaves' to each, and are gradually succeeded by five- and six-membered

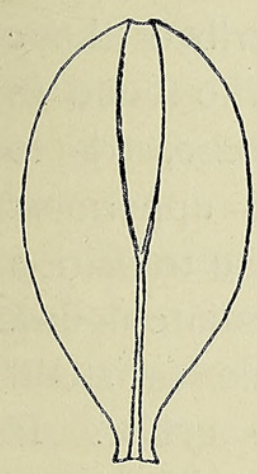

FIGS. 23 .

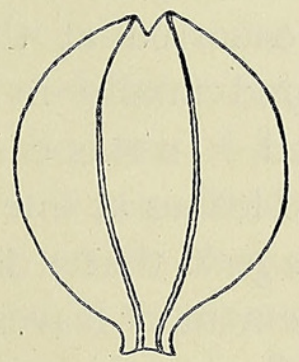

24 .

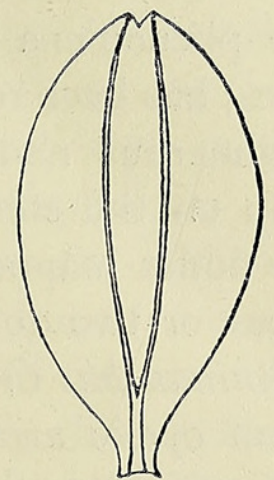

25 .

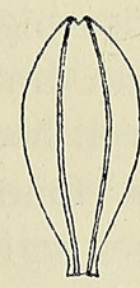

25.

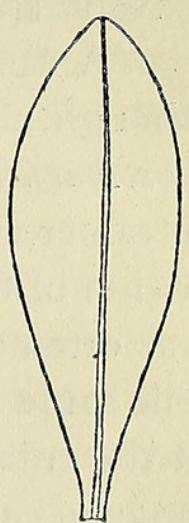

27.

Figs. 23-27. Asperula trifida, Makino. 23-26. Double stipules. 27. True leaf from the node at which the double stipule delineated in Fig. 26 is borne. All $\times 5$.

whorls, as the branches become elongated. ${ }^{2}$ In the same series of specimens the writer found two cases in which one of the stipules of a fivemembered whorl had two midribs. The arrangement of the 'leaves' on one of the branches is as follows: the first node has two true leaves and two stipules, one of the latter having two midribs; the second node is four-membered, both of the stipules being normal; the third node fivemembered, one of the stipules again having a double midrib (Fig. 22); while the fourth whorl is just sprouting, thus preventing the determination of the number of 'leaves' with accuracy.

The examples described above clearly show that double stipules may occur in any part, but more often near the base, and also towards the apex of a stem. It may also be remarked that double stipules fall on the whole into two categories, according as they form a transition towards increase or decrease in the number of 'leaves' in a whorl. In other words,

1 Fl. Orient., vol. iii (1875), p. 28. The plant was originally described as Crucianella aspera, M. Bieb. : Fl. Tauıico-Caucasica, vol. i (I808), p. Io7.

2 A similar feature is also found in G. Aparine, Linn. In the seedling of this species, and also of others belonging to the Stellatae, branches are very frequently produced in the axil of the cotyledons. 
double stipules may be produced in the region in which the number of 'leaves' is undergoing increase, or on the other hand reduction from node to node. It is evident that at the base of a seedling a double stipule represents a stage of progression, while towards the apex of a stem it usually represents a stage of retrogression. It has already been pointed out that in the Stellatae the four-membered whorl seems to represent within the limit of possibility the most primitive type. Hence it follows that the progression generally speaking would have been from the four-membered whorls to those with six or more members by fission of the original two stipules. In the case of any 'four-leaved' species, such as Galium gracile, the occurrence of double stipules therefore indicates a step towards the production of 'fiveleaved' species.

A case presenting some phenomena similar to those described above (though not involving stipules) has been recorded by Groom, ${ }^{1}$ who found in Lysimaihia vulgaris that dimerous nodes occurred at the base, tri- to tetramerous nodes higher up on the stem, and finally in the uppermost region of the stem dimerous nodes reappeared. In this case the transition was often accomplished by one or two double leaves at intermediate nodes. The same author ${ }^{2}$ found in Rhinanthus Crista-galli that a double leaf stood at the transitional region from cyclic arrangement of leaves to acyclic. It appears certain that in the former case (i.e. Lysimachia) the double leaves represent on the whole in the lower region of the stem a stage of progression, and in the upper region one of retrogression. In the latter case (i.e. Rhinanthus) the double leaf doubtless represents a stage in the complete replacement of two opposite leaves by a solitary leaf, by means of a concrescence. ${ }^{3}$

In dealing with double stipules (and double leaves), it should be borne in mind that the foliar organs of this nature may sometimes be produced without relation to the general tendency of arrangement and distribution of 'leaves' in the stem. Some of the cases above described may again be referred to. In the case of Galium leiophyllum a four-membered whorl near the base of a stem is succeeded by a five-membered whorl, thus showing a tendency of increase in the number of 'leaves'. At the next node the whorl is again four-membered, but one of the two stipules has two midribs (Fig. 2I), apparently indicating a transition towards decrease in number. The next whorl is however again five-membered, and all the nodes (about four have so far developed) succeeding this particular one are six-membered. In the examples of Asperula trifida, which have been described above in detail, the number of members at succeeding nodes does not show a regular

1 Longitudinal Symmetry in Phanerogamia. Phil. Trans. Roy. Soc. Lond., B, vol. cc (1908), p. 84 et seq.

2 Groom, 1. c., p. Io6.

3 For further instances of similar phenomena see Worsdell, Principles of Plant-Teratology, vol. i (I9I5), p. 2 I 6 et seq. 
sequence, but repetition of increase and decrease may be seen. In such cases, double stipules may be clearly associated with either increase or decrease, or sometimes a decision on the subject may be impossible. ${ }^{1}$ At the same time it may be noticed in many cases that in alternate nodes the number of the 'leaves' and also the nature of the stipules are more closely correlated than in successive ones.

Explanations may be sought for partly in some physiological factors which either promote or retard the growth of a plant. Boodle ${ }^{2}$ found in the seedlings of the gorse that similar irregularities often occurred regarding the distribution of the trifoliate leaves. He is of opinion that this is at any rate partly due to variation in some physiological conditions during the growth of the seedlings. On the other hand, Groom's suggestion ${ }^{3}$ regarding a similar phenomenon exhibited by Lysimachia vulgaris, that 'morphogenous impulses are transmitted along the orthostichies', may give the explanation of the alternating number of members at succeeding nodes described in some of the above examples.

Turning to the case of a seven- or eight-membered whorl, it may be held that the middle stipule of the three (on one or both sides of the node) has originated by fission from one of the two adjoining stipules. Since the middle stipule usually takes exactly the median position and assumes the same size as the others, its relationship to the one or the other of the two adjoining stipular members cannot be determined. This occurrence may conveniently be termed a congenital fission (chorisis, dédoublement) in contrast with the phenomenon known as congenital fusion. If this congenital fission once starts in any species it may be repeated more than once, resulting in the production of as many stipules as space will permit on either side of the node. Hence, we more often find the pleiomerous whorls in the species with narrow 'leaves' and a comparatively thick stem, such as Galium verum.

In the case of the pleiomerous whorls, stipules are known to occur as many as five on either side, and they probably develop from as many primordia as there are stipules, without showing any connexion with one another.

A parallel case may be found at the cotyledonary node in many of the Conifers and a few Dicotyledons, in which the two original cotyledons have undergone chorisis, thus giving rise to a polycotyledonous condition. In these cases the increase in the number takes place as a rule without any transitional stages, and double cotyledons are not frequently in evidence. The double cotyledons recorded by Groom ${ }^{4}$ for Acer Pseudoplatanus ${ }^{5}$ and

1 Cf. Worsdell, 1. c., p. $23^{8}$.

${ }^{2}$ On the Trifoliate and other Leaves of the Gorse (Ulex europaea, L.). Ann. Bot., vol. xxviii, (I9I4), p. 527 et seq.

${ }^{3}$ Groom, l. c., p. 86.

5 Also see Worsdell, 1. c., p. $21_{5}$, Pl. XIX, Fig. $4 a$.

${ }^{4}$ l. c., pp. 102-3. 
Fraximus excelsior, by Miss Chick ${ }^{1}$ for Torreya Myristica, and by Hill and de Fraine ${ }^{2}$ for Cupressus torulosa, Abies sibirica, Pinus montana var. gallica, $P$. contorta var. Murrayana, Araucaria Cunninghamii, \&c., are therefore worthy of notice.

From the evidence given above, the conjecture may be justified that the direct ancestors of the Stellatae possibly had two stipules at each node, and that each one of these two stipules had been derived by means of congenital concrescence from two separate stipular organs, the earlier ancestors of the Rubiaceae as a whole being assumed to have possessed four stipules at each node. Hence, it follows that the species of Galium (and also of any other genera of the Stellatae) having four-membered whorls would on the whole represent the most primitive type in that particular tribe. Whorls with six foliar organs would thus be regarded as a more advanced type among the Stellatae, but at the same time as representing a reversion to the condition found in the ancestors of the Rubiaceae. It is suggestive that among living Rubiaceae cases of concrescence of stipules occur very frequently, and in certain genera, such as Palicourea, Cephaelis, \&c., some species have four separate stipules, while others have two either partially or completely fused (connate) ones, thus resulting in the production of fourmembered whorls.

Regarding the stage of evolution at which the stipules assumed the characters of true leaves in the Stellatae, it is difficult to come to a decision. However, it is beyond all doubt that the original type of the stipules in the Stellatae was scale-like, and that the leaf-like stipules have evolved from that type, probably in relation to certain physiological necessities. It may therefore be considered that in this respect Aidymaea mexicana stands nearest the prototype of Stellatae, as Goebel maintains, ${ }^{3}$ and that Galium paradoxum represents the most primitive species of its genus. As to the question whether Galium geminifolium and Asperula geminifolia, both of which usually bear two scale-like interfoliar stipules at each node, ${ }^{4}$ furnish us with further examples of primitive species is rather doubtful. The production of scale-like stipules in these two species may probably have been brought about by the circumstances of their xerophytic habitat, thus indicating reduction rather than a retention of the primitive state.

\section{SUMMARY.}

I. In Galium and other allied genera, each stipule as a rule develops from a single primordium.

2. Fairly frequently, and particularly in four-membered and rarely in

1 The Seedling of Torreya Myristica. New Phytologist, vol. ii (I9o3), p. 85 .

2 Seedling Structure of Gymnosperms, II. Ann. Bot., vol. xxiii (I909), p. 22I, Pl. XV, Fig. $4 b$.

3 Organography of Plants (Engl. ed.), pt. 2 (1905), p. 37 I.

${ }_{4}$ Cf. the present paper, p. 203 , foot-note. 
five-membered whorls, stipules may be found which have been produced as the result of a coalescence of two primordia. Stipules of this kind (=double stipules) possess either a forked midrib or two separate midribs, the apex of the stipules being at the same time more or less two-lobed.

3. Double stipules may occur near the base, or towards the apex, and more rarely in the middle region of a stem. They may in certain cases represent a transition towards increase in number, in other cases a stage leading towards numerical decrease of the organs. Double stipules forming examples of both of these cases are occasionally found on one and the same stem. Sometimes, however, a decision on this subject is hardly possible.

4. In the seedlings of several species examined of the genera Galium, Asperula, Crucianella, and Mericarpaea, the node or sometimes a few nodes succeeding the cotyledonary node as a rule bear a four-membered whorl, consisting of two true (opposite) leaves and two stipules alternating with the former. In the higher region of the stem the number of members in a whorl may in some of the species examined be gradually increased up to eight.

5. The four-membered whorl is considered to represent the primitive type, at the same time indicating the probable character which prevailed among the direct ancestors of the Stellatae.

6. The six-membered whorl, which probably represents the type that characterized the ancestors of the Rubiaceae, is in the Stellatae regarded as having been derived from a four-membered whorl by complete fission (dédoublement) of the two stipules into four.

7. Whorls with more than six members have no doubt originated by repeated fission of the original two stipules.

8. Diaymaea mexicana, Hook. fil., which bears two opposite leaves, and from two to often six, or rarely seven, scale-like stipules at each node, is presumed to approach the prototype of the Stellatae. And in this species also the four-membered whorl very probably represents the most primitive type.

9. Galium paradoxum, Maxim., which bears two leaves and two scalelike stipules at the lower nodes and two true leaves and two leaf-like stipules in the higher region of the stem, is believed to be the most primitive species of the genus in this respect.

The present investigation has been carried out in the Herbarium, Royal Botanic Gardens, Kew. All the specimens, except those of Galium saxatile and $G$. Aparine, used for the investigation are preserved in the Herbarium. The writer has great pleasure in expressing his sincere thanks to Sir David Prain, C. M. G., C. I. E., for the privilege of working in the Herbarium and also using the Library. The writer also takes this opportunity of thanking Mr. L. A. Boodle for the constant encouragement, valuable help, and the interest he has taken during the progress of the investigation. 


\section{POSTSCRIPT.}

After the above had been written, some of the seedlings of several members of the Stellatae raised in a hot-pit in the Royal Botanic Gardens, Kew, were found ready for an investigation. The result of an examination regarding the number of members at lower nodes in the stem is as follows :

I. Galium Aparine, Linn. The seedlings bore a four-membered whorl at the first node succeeding the cotyledons. Only one specimen was found to have produced a five-membered whorl at the first node. Thus, the result corresponds to what has been observed in the field, as described in the foregoing pages.

2. Galium Mollugo, Linn. $\times G$. verum, Linn. So far, the seedlings have produced three nodes, at each of which four 'leaves', consisting of two true leaves and two stipules, are present. The stipules are as a rule similar to the true leaves, but a scale-like stipule occasionally stood opposite a normal, leaf-like stipule.

3. Asperula galioides, Bieb. ${ }^{1}$ So far, four nodes have developed in the seedlings examined. Four 'leaves' were present at each of the four nodes. The stipules are sometimes smaller than the true leaves in the same whorl.

4. Asperula tinctoria, Linn. ${ }^{2}$ So far, three nodes have been produced, each of which is four-membered. The stipules are distinctly smaller than the true leaves at the same node, often assuming a scale-like appearance.

1 According to de Candolle (Prodr. Reg. Veg., vol. iv, p. ${ }^{85}$ ) this species bears six to eight 'leaves' to the node.

2 According to de Candolle (1. c., p. $5^{82}$ ) the whorls in the lower region of the stem are sixmembered, those in the middle region are four-membered, while those in the apical region are twomembered. 


\section{$2 \mathrm{BHL}$ Biodiversity Heritage Library}

Takeda, H. 1916. "Some points in the morphology of the stipules in the Stellatae, with special reference to Galium." Annals of botany 30, 197-214. https://doi.org/10.1093/oxfordjournals.aob.a089591.

View This Item Online: https://www.biodiversitylibrary.org/item/237452

DOI: https://doi.org/10.1093/oxfordjournals.aob.a089591

Permalink: https://www.biodiversitylibrary.org/partpdf/320109

\section{Holding Institution}

Smithsonian Libraries

\section{Sponsored by}

Biodiversity Heritage Library

\section{Copyright \& Reuse}

Copyright Status: Not in copyright. The BHL knows of no copyright restrictions on this item.

This document was created from content at the Biodiversity Heritage Library, the world's largest open access digital library for biodiversity literature and archives. Visit BHL at https://www.biodiversitylibrary.org. 